\title{
7. Sacralising the profane, profaning the sacred
}

\section{Colin Tatz}

Genocide produces anomalies. One example is the coincidence and coexistence of two diametrically opposed views of the same catastrophe. Some victims make sacred, or sacralise, their profoundly profane experience; some perpetrators, or their supporters, deliberately profane that now sacralised event.

Sacrilege and blasphemy have a common element: desecration and violation of the sacred rather than mere irreverence towards that which some people hold in high regard. Victims of genocide-Armenians and Jews, among others - venerate their dead, their 'cleansed', their relocated or removed people. Definable groups perish in the killing fields, or somehow disappear forever from populations and places. The survivors revere their kin and need to commemorate those events in order to maintain their ethnic coherence and their sanity and to preserve a modicum of truth in history. At times, however, reverence loses its restraints and the profane events themselves become sacralised.

The most malignant form of desecrating the victims is the subsequent denial of their catastrophe: the dead did not die in the fields and should not appear as 'cleansed' in the history books. Their sculpted memorials are defiled because they deny the integrity and dignity of the 'alleged' perpetrators. The worst of the world's perpetrators, Heinrich Himmler, once insisted that the essence of Nazi behaviour was their very 'decency'. ${ }^{1}$ And today, in several Baltic states, convicted war criminals have public monuments attesting to their 'heroism'.

Sacralising the profane is not in the same league of indecency as profaning the sacred. However, it warrants attention because it tends unwittingly to confuse soothing the souls of the victims or of their families with warding off repetition of the catastrophe.

\section{Sacralising what isn't sacred}

In the 90-odd years since the onset of the Armenian genocide in Turkey, the catastrophe of 1.5 million dead has become enshrined in many ways. Monuments have been built in many Western countries. Western governments, at the national and regional levels, and city authorities, have publicly recognised that event as genocide. The twenty-fourth day of April each year is commemorated with an increasingly religious flavour and fervour. The day has become a rallying point for diaspora Armenians, at a time and a place where many congregate in large numbers for perhaps only that one day in the year. As time passes, so the 
Armenian genocide is increasingly researched, examined, presented, discussed, and brought to a level of significance formerly reserved for the Holocaust. Hitler's oft-repeated rhetorical question posed in 1939- 'who after all remembers the Armenians?' - has been more than counter-balanced by a near-universal recognition of this second ${ }^{2}$ cosmic genocide of the twentieth century.

A sacral patina covers this event, as it does the Holocaust. It has become not just a focal point but the fulcrum of Armenian identity. Armenianness, as with Jewishness, coheres around the catastrophe, often relegating earlier and other more significant historical, cultural and religious endeavours and achievements into the byways of memory and overshadowing more recent experiences and achievements in which pride can be taken. Children are taught to locate their identity through these genocides. Formerly homeless, friendless and defenceless minorities, both peoples are now independent (armed) nations, seemingly born out of these genocidal events, united in a determination to prevent repetition of their earlier fates.

In this context, the Holocaust poses a more extreme case. For many, that tremendum has become a sacred event, metahistorical, beyond words, analysis and deconstruction. It was no accident that Elie Wiesel, the renowned Auschwitz survivor and Nobel Laureate, declared his preference for the word 'Holocaust' to identify the Judeocide. The small-h Greek word was first used by Marion Harland and J. Castell Hopkins in their late-1890s books, referring to this gigantic holocaust with all its attendant horrors of flame, rapine and violation' ${ }^{3}$ They were describing the 1894-96 Armenian genocidal massacres ordered by Turkey's Sultan Hamid II.

Wiesel's preferred capital-H word resonated with this Greek term, holokauston, meaning the destruction of everything by burning. He very much wanted to incorporate a notion of sacrifice - in this case, what we call the Abraham-and-Isaac model of religious explanation of the Holocaust. But even here there is an unintended and curious blasphemy. As a test of Abraham's faith, a beneficent God ordered him to bind his son Isaac for sacrifice. Abraham did not hesitate. Seeing such purity of faith, God sent an angel of mercy and substituted a ram for the slaughter. But in Auschwitz, Belzec, Sobibor, Majdanek, Chelmno, Kulmhof, and Treblinka there were only malevolent 'angels of death' and no four-legged last-minute substitutes. ${ }^{4}$

The Judeocide - which many now prefer to call the Shoah ${ }^{5}$ (the Hebrew word for destruction) - was the world's most profane act in modern history. Six million Jews and close to 40 million non-Jews died in Hitler's war against world Jewry. After the Nazis had emulated many of the Turkish modes of murdering the Armenians, they became truly 'inventive', conceiving and putting into practice the idea of creating death as an end in itself. The chosen method was the industrialisation of the killing process on a gigantic scale. Thus the killing 
factories - for which sole purpose Belzec, Sobibor and Treblinka existed - could 'process' between 12000 and 15000 stukke (pieces) every 24 hours. They did this to 2.7 million Jews between February 1942 and November 1944.

Metahistorical? Sacred? In the first blush of discovery and dissemination there was only dumbfoundedness. Wiesel's first reaction was typical: 'the time has come for all of us to learn and to be silent'. Even as late as 1985, Wiesel would write:

We do not know how to handle it. We did not know what to do before it occurred: we were totally disoriented while it occurred; and now after it we have acquired a unique knowledge from it that may crush us. We simply did not know what to do with such knowledge. It goes deep into the nature of man and has extraordinary implications about the relationship between man and man, man and language, man and himself, and, ultimately, man and God. We don't know: at the beginning that is the answer to it, and I am afraid at the end as well. ${ }^{6}$

Nonetheless, as Holocaust historian Yehuda Bauer has never tired of saying, this was a human event perpetrated by one group of human beings on another group of humans, in the middle of Europe in the middle of the twentieth century; it must therefore be explicable. To be silent is a counsel of despair. And so Bauer, and many others, researched, examined, delved, excavated (literally and metaphorically), analysed and thereby established a forensic history that meticulously re- or de-constructed what happened: where, to whom, by whom, when, and even why. Such precise and corroborated detail has had to withstand not only cross-examination in war crimes trials but also the bizarre claims of the denialists.

Yet there is a dreadful irony in all of this. At one level, there is an enormous growth in Holocaust research and writing, an increase in memoirs, memorialisation ceremonies, in marches of the living to Auschwitz, in archaeological excavations of mass graves, in trials of old men, in documentary and commercial films on genocide in general. At another level, there is the stubborn effort of many survivors to resist, even to reject, historical analyses. They see an 'answer' of sorts, some kind of prophylaxis or prevention of repetition in more memorials, bigger museums, more candle-lighting memorial ceremonies. The glass cases housing documents and memorabilia have become shrines and amulets, akin to mezuzot - the verses from Deuteronomy affixed in capsules on the doorposts of most Jewish homes - to both affirm faith in God and to ward off demons. But it can never be an 'answer', an antidote, a preventive measure that ensures 'Never Again!' Preserving historical truth and simultaneously preventing a recurrence of those events needs methods very different from this approach. 
Had I survived a camp, no doubt I would want that hell frozen in time, preserved for the world to witness. I would not want my experience buried amidst the generalisations, or even amongst the detailed specifications, of broad historical abstractions. I would want candles, prayers, and imprecations of 'Never Again!'. And I would be sacralising both the banality and the profanity of unalloyed evil as I did so.

All genocides are human events, with human perpetrators, victims, bystanders, beneficiaries and denialists. As a genocide studies historian, not a survivor, I search for reasons for their behaviours, not psychologically, but historically, politically and legally. I try to find the microscopic black pinheads of malignancy which form the origins of genocide, the sources and resources of the ideologues, the justifications given for their decisions, their adoption of 'biological' solutions to social and political problems, the responsibility and accountability of those who give and those who carry out orders. For me, nothing in deliberate starvation, forced death marches, poisoning, drowning, shooting and gassing can ever be sacralised. There is no room, in my view, for a new secular religion which enshrines these events.

Several authors have dealt with the so-called 'Shoah business', notably Tim Cole, Peter Novick and Norman Finkelstein. ${ }^{7}$ In varying degrees they abhor the packaging, selling and misuse of the Holocaust as an industry, a guilt-producer, an antidote to anti-Semitism, 'a way of shaking down Swiss banks' [!], a protection against criticism of Israel's Palestinian policies. They inveigh against the unnamed 'guardians' of the Holocaust, those who turn that event into all manner of myth and kitsch. But I often have trouble distinguishing whether these critics are attacking this 'shrinological' guardianship — or the very subject matter being guarded.

\section{Blaspheming the sacred and the profane}

The French classical scholar, Pierre Vidal-Naquet, labelled denialists 'the assassins of memory'. In the case of the Jews, the denialists are not always the génocidaires; in the case of the Armenians, however, they are.

Turkish denialism of the genocide of 1.5 million Armenians is official, riven, driven, constant, rampant, and increasing each year since the events of 1915 to 1922. It is state-funded, with special departments and units in overseas missions whose sole purpose is to dilute, counter, minimise, trivialise and relativise every reference to the events which encompassed a genocide of Armenians, Pontian Greeks and Assyrian Christians in Asia Minor.

In the face of irrefutable evidence of genocide, Turkey has created a massive industry of denialism. Its actions are spectacular, often bizarre, lacking any effort to distinguish between the serious and the silly. In the 1930s, Turkish pressure was put on the American government and on Hollywood studios not 
to proceed with an embryonic film based on Franz Werfel's 1932 novel, Forty Days at Musa Dagh, which depicted Armenian resistance. In the present era, there has been heavy lobbying of the American Congress not to find a path to the two-thirds majority needed for a resolution recognising the genocide. Successful lobbying led to the removal of any reference to genocide in the Armenian entry in the Encyclopaedia Britannica. Recently, there have been threats to sever diplomatic relations with France over the French declaration that there was such a genocide. In April 2001, the Turkish government somehow squeezed Shimon Peres, then Israel's foreign minister, to say in Ankara that 'Armenian allegations of genocide are meaningless' . (Not even Israel's geopolitical interests in a time of crisis can condone such a statement; at worst, he could have said nothing.)

There was a demand a few years ago to SBS television in Sydney that the station pulp its 25-year anniversary history book because it twice made passing reference to an event 'that never happened'. Then there was an extraordinary visit by His Excellency the Ambassador to my office at Macquarie University in 1987 in which he sought to have me delete the Armenian segment of my new course on 'The Politics of Genocide'.

What still motivates Turkey around the globe? We don't know, but I suggest the following:

- A suppression of guilt and shame that a warrior nation, a 'beacon of democracy' as it saw itself in 1908 (and since), slaughtered several ethnic populations. Democracies, it is said, don't commit genocide; ergo, Turkey couldn't and didn't do so.

- A cultural and social ethos of honour, a compelling and compulsive need to remove any blots on the national escutcheon.

- A chronic fear that admission will lead to massive claims for reparation and restitution.

- To overcome fears of social fragmentation in a society that is still very much a state in transition.

- A 'logical' belief that because the genocide was committed with impunity, so denial will also meet with neither opposition nor obloquy.

- An inner knowledge that the juggernaut denial industry has a momentum of its own and can't be stopped even if they wanted it to stop.

The work of those who contend, or who may even believe, that the Holocaust was and is, in Arthur Butz's language, 'the hoax of the twentieth century' has been analysed by, among others, Lucy Dawidowicz, Deborah Lipstadt and Pierre Vidal-Naquet. We now know a great deal about denialist writings, techniques and vehicles, and about their effectiveness or lack thereof. Apart from tolerance of that especial brand of denialism, so-called 'comparative trivialisation', propagated by Ernst Nolte $(1985,1988)$ and Andreas Hillgruber (1986) in 
Germany, there has been no denial by the German state, East, West or re-united. The Schuldfrage (guilt question) remains a central issue in daily German life, especially among the young. Perversely, perhaps, there has been a great deal of denial in the very democracies where freedom of speech is sacrosanct: France, the United States, Canada, Britain and Australia. We may well ask why this has happened. I offer a number of reasons.

\section{Denialism in the democracies}

- In the early post-war years, denialism was believed to facilitate the 'coming out' of Nazis and Nazis in hiding. Only the nullification of the Holocaust could make Nazi-ness, and its derivatives, respectable or acceptable.

- Denialism strives to re-legitimise anti-Semitism as a political credo. This is only possible if anti-Semitism is sanitised of its practical apotheosis - Auschwitz. Political and nationalistic anti-Semitism, and political parties devoted thereto, prevalent across Europe before World War II, are undergoing a resurgence in today's Europe.

- Denialism aims to legitimise fascism as a worthy, organic political philosophy. This is only possible if you can divorce fascism from its associated death camp anti-Semitism. If the death camps can be successfully denied, then fascism and anti-Semitism can have nothing to be ashamed of and can, once again, be respectable.

- Denialism serves to disestablish the legitimacy of Israel if, indeed, Israel is the consequence and outcome of the Holocaust. This unfortunate and misleading Holocaust = Israel equation, strongly (and, I believe, wrongly) emphasised by former prime ministers David Ben-Gurion and Menachem Begin, is still, regrettably, pervasive throughout Israel and the Diaspora. If, therefore, the Holocaust can be denied, then so, too, can any rationalisation for the foundation and continued existence of the Jewish state.

- Denialism helps establish the legitimacy of the Palestinian cause. By turning Palestinians into the victims, Jews are accused of behaving like the very Nazis whom the Jews 'falsely' accuse of genocide. Radical Islam has now adopted all the techniques of an earlier European-Christian anti-Semitism, including Holocaust denialism.

- Denialism is used to reconcile the Soviets' notion of the centrality of their own history of millions lost and their antagonism, especially after the 1967 war, to a Jewry, an Israel or a Zion that has, since 1945, had the pre-eminent claim on having lost six million of its people. To avoid that contradiction, Soviet academicians turned the Nazis into fascists and didn't mention the centrality, in the Nazi weltanschauung, of anti-Semitism and the 'Final Solution'. In the end, for them, and for the ears of a world that may have been willing to listen, the only victims of fascism were communists. This phase - together with the Soviet system - has now passed, but it was, for 
decades, a state-sponsored enterprise in the major academies, more vigorous, more pernicious and much more effective world-wide than the 'free-enterprise' efforts of a handful of American denialists like Elmer Barnes, Willis Carto and Arthur Butz.

- Denialism counteracts irrational fears of a breaking-up of social consensus in society, particularly when a society is in transition. To focus public attention on an alleged, ethnically identifiable fifth column of 'others' offers some grounds for a form of national unity.

- Denialism can magnify, in some instances, a particular victim community's suffering without having to have it compared with, and to be found to be on a lesser scale than, the Holocaust. Deliberate flattening, or even minimising, of the Holocaust magnifies and equalises all atrocities. In a morbid sense, if everyone commits horrors, then not only is no person or group any more guilty than any other, but all humankind has suffered equally - and Jews, therefore, have no greater claim on humanity's conscience.

- Denialism offers a form of ready expression of the hatred of Jews.

- Denialism can hurt, shafting corpses with the added indignity of claiming that there were no corpses, and can inflict on Jewish survivors the accusation, even the curse, that their nightmares are just that - very bad dreams. In the words of Vidal-Naquet: denialists 'are intent on striking a community in the thousand painful fibres that continue to link it to its own past' ${ }^{\prime}{ }^{8}$

Certainly these denialists know what they're doing: they learn, refine, become more 'academic', more sophisticated, more credible as alternative explainers or revealers of 'truth'; more subtle and less 'kooky' than they appeared immediately after the war. But while they remain professionally isolated within their communities, they are at the same time collectivised. In other words, as disparate as they are geographically, they have turned themselves into a coterie, a cult, a collective who now meet publicly - or who are sometimes prevented from meeting publicly, as in Lebanon in 2001. ${ }^{9}$ They are assembled in a fortress of their choosing, as purveyors of hate and merchants of prejudice. While they may have a certain mass appeal, they are no longer viewed as discrete, independent scholars, worthy of attention or of a serious intellectual or academic hearing. They see themselves as an army of combatants, although their visibility renders them more capable of being grouped into an identifiable body, quartered, quarantined and made both ridiculous and unbelievable.

In 2000, and again in 2001, on appeal in senior British courts, the hubris of the new Crown Prince of ridicule, David Irving, 'the noted British historian, author of more than 20 books', ensured that a great many Humptys fell off the wall. ${ }^{10}$ In July 2001, the three-judge Court of Appeal supported Justice Gray's initial ruling in the libel case of Irving $v$ Lipstadt \& Penguin Books. They declared that Irving was 'one of the most dangerous spokespersons for Holocaust denial...No 
objective, fair-minded historian would have serious cause to doubt that there were gas chambers at Auschwitz and that they were operated on a substantial scale to kill hundreds of thousands of Jews.' Justice Gray had concluded: 'Irving is anti-Semitic. His words are directed against Jews, either individually or collectively, in the sense that they are by turns hostile, critical, offensive and derisory'. ${ }^{11}$

\section{Australian conundrums}

These are case studies about what an Australian High Court judge once said were about faraway people in faraway places. In our different context, one seemingly benign and beneficent, we have a case of sacralising that which isn't so and a profaning of that which is.

The agitation for Aboriginal land rights in the late 1960s resulted in the Fraser Coalition government's enacting what the Australian Labor Party had begun in 1973: a statute in 1976 to enable Aborigines to claim vacant Crown land in the Northern Territory. Aided by some dubious anthropology, the mechanism for land acquisition in the Aboriginal Land Rights (Northern Territory) Act is peculiar, to say the least. Land was not to be allocated on the basis of need, as with some Indian lands in the United States. There is no argument about prior occupation, or adverse possession, or continued possession, as in the case of the Inuit in Canada and the Maori in New Zealand. Claimants have to be Aboriginal, with demonstrable patrilineal, matrilineal or ambilineal lines of inheritance; they have to have spiritual attachment to the land and must be able to demonstrate the strength of that spiritual attachment by way of ceremonial duties. What underlies this curious mechanism is the [white] belief that all Aboriginal land involves spirituality and is therefore sacred. Some land is, indeed, sacred, as we will see, but much, even most, of Aboriginal land is or was camping ground and hunting ground, land which is hardly profane but which nonetheless has no under- or over-lay of sacredness.

In 1976, the Federal Government's Land Fund Commission bought the pastoral lease of Noonkanbah Station for the Yungngora people of the Kimberleys. ${ }^{12}$ In the diamond and oil rush of the time, over 500 mining claims, most of which were contested successfully by lawyers for the Aborigines, were lodged on that property. Amax Iron Ore Corporation held a five-year valid exploration permit to drill for oil. In 1979, they sent in a bulldozer to dig up ceremonial land near the homestead, named ' $\mathrm{P}$ ' or 'Pea' Hill. Trustees appointed under the Heritage Act told the Mines Minister that to drill there 'would affect the site by contradicting past and current Aboriginal sacred beliefs'. The Minister ordered the Trustees to give their consent. Thereupon, the Aborigines locked the Noonkanbah gate and refused all entry. Several legal injunctions later, this Dreamtime $v$ Oil issue became very political. The Premier, Sir Charles Court, commandeered the private company's oil drilling rig and sent the massive 
machine to Noonkanbah, accompanied by an enormous armed police convoy. There was a sense of outrage across Australia at this display of force, with the National Times calling the Premier Sir Charles Rommel. The point of this story is that Amax knew from geological experts that no oil was to be found at ' $\mathrm{P}$ ' Hill-yet Court was intent on not only defying conservative federal Coalition notions on Aboriginal land, but also on defying and decrying any conceptions that Aborigines had a belief system worthy of respect. In an act of conscious desecration, Court drilled and of, course, no oil was found.

\section{'Forgiving and forgetting'}

In Australia, and elsewhere, there is a new catchcry: reconciliation, a call to the offended to 'forgive and forget', to 'move on'. No one is willing to discuss what victim groups must move on from. If the politics of remembering the feuds, the hatreds, and the differences produced cataclysmic deaths, then surely, they say, it must be replaced with an ideology of forgiving and forgetting.

There are, as I wrote elsewhere, ${ }^{13}$ costs in this new fashion, costs to the victims, whether Armenian, Jewish or Aboriginal. It is they who must forgo the desire or deny their need for retributive justice. It is they who must eschew notions of guilt and atonement and, all too often, forgo compensation for harms done. It is they who must agree to the diminution, or even abolition, of that shared historical memory which holds victim groups together. It is they who must concur in the substitution of their memory by our memory and their history by our history. The Forrest River massacres were not massacres - or so we are told - and the places of such events are of no moment, let alone veneration. But Gallipoli - where thousands of young Australians were senselessly mown down in their thousands - is officially 'a sacred site', a shrine to our birth as a nation. The victims must connive at ignoring the importance of accountability for the crimes committed against them, and it is they who must agree to the obliteration of that responsibility. It is they who must cease reacting so hysterically against denialism, that major tributary of forgetting, which claims that there was nothing to remember in the first place. Such is the profanity of their being asked to 'move on'.

\section{ENDNOTES}

1 Himmler to senior SS officers in Poznan, 4 October 1943: [explaining the 'Final Solution] 'To have stood fast through this and - except for cases of human weakness - to have stayed decent, that has made us hard... We do not want, in the end, because we destroyed a bacillus, to be infected by this bacillus and to die. I will never stand by and watch while even a small rotten spot develops or takes hold. Wherever it may form we will together burn it away. All in all, however, we can say that we carried out this most difficult of tasks in a spirit of love for our people. And we have suffered no harm to our inner being, our soul, our character...' in Arad, Y., Gutman Y. and A. Margolit, 1981, Documents on the Holocaust, Yad Vashem, Jerusalem, pp. 344-5.

2 The first genocide of 'the century of genocide', the twentieth century, was the destruction of some 60000 Herero people by their German colonisers in German South-West Africa (now Namibia) in 1904-05. 
3 Harland, Marion 1897, Under the Flag of the Orient: the Thrilling Story of Armenia, Philadelphia, Historical Publishing Company, p. 415; Castell Hopkins, J. 1896, The Sword of Islam or Suffering Armenia, Brantford, the Bradley-Garretson Co. Ltd. At p. 313 he talks about 'the full glare of the national holocaust upon the altar of Mahometan cruelty'.

4 See Tatz, Colin 2003, With Intent to Destroy: Reflecting on Genocide, London, Verso, pp. 33-9, for discussion of Jewish religious responses to the Holocaust.

5 Orthodox Jews in Israel tend to use the word Churban/Hurban for the destruction of European Jewry. Arno Mayer, 1990, in his Why Did the Heavens not Darken?: the 'Final Solution' in History, New York, Pantheon Books, used the word Judeocide - the killing of Jews - a term I prefer for its directness.

6 Wiesel, Elie 1985, Against Silence: the Voice and Vision of Elie Wiesel, Irving Abrahamson (ed.), New York, Holocaust Library, 3 vols, p. 287.

7 Cole, Tim 1999, Selling the Holocaust: from Auschwitz to Schindler, How History is Bought, Packaged, and Sold, New York, Routledge;Novick, Peter 2000, The Holocaust in American Life, New York, HoughtonMifflin; Finkelstein, Norman 2000, The Holocaust Industry, London, Verso.

8 Vidal-Naquet, Pierre 1992, The Assassins of Memory, New York, Columbia University Press, pp. xxiii-xxiv.

9 In March 2001, 14 Arab intellectuals denounced the projected denialist conference scheduled to be held in Lebanon. The influential London Arab newspaper, Al-Hayat, editorialised that such conferences 'disgraced Lebanon'. Ha'aretz, English edition, 20 March 2001. However, in June 2001, such a conference was held in Jordan.

10 Evans, Richard 2001, Telling Lies About the Hitler: the Holocaust, History and the David Irving Trial, London, Verso; Guttenplan, D. D. 2001, The Holocaust on Trial, New York, W.W. Norton.

11 Evans, 2001, p. 236.

12 See Tatz, Colin 1982, Aborigines and Uranium and Other Essays, Heinemann, pp. 90-92.

13 Tatz, Colin 'Reflections on the Politics of Remembering and Forgetting', The First Abraham Wajnryb Memorial Lecture, Macquarie University, 1 December 1994, Centre for Comparative Genocide Studies. 